\title{
冬期道路情報管理
}

\section{Managing Information for Winter Road Maintenance}

\section{冬期道路情報管理（その3） \\ 一 北海道の冬期道路情報システム -}

\section{Managing Information for Winter Road Maintenance (Part III)}

- Managing Information System for Winter Road Maintenance in Hokkaidou Area -

原文 宏*

Fumihiro Hara
1.はじめに

冬期の道路交通に係わる情報関連の施策は，情報 を利用する対象によって大きく2つに分類される。 一つは，機械除雪やロードヒーティング，凍結防止 剂散布などの除雪作業を効率的に安全に行うことを 目的に，作業開始の意志決定や作業機械のオペレー ター支援として実施される。

もう一つは，主に道路を使う自動車のドライバー や一般市民に対して実施されるもので，除雪状態， 気象状況，交通状況を提供することによって，危険 回避を促し，混乱を最小限に導くために奏施される ものである。

本報告では，このような冬期の道路交通に係わる 気象，交通，路面等の情報を収集，加工，提供する システムについて，北海道に㧍ける変遷と現状を紹 介するとともに，研究や実験の現状をリビューし， 今後の展望について考察する。

\section{2. 北海道における冬期道路情報システム} の進展と背景 ${ }^{1.2}$

昭和 25 年 7 月，北海道土木部及び自動車業界が連 携して「北海道道路運送冬期対策協議会」を結成し た。協議会では北海道全体を対象に除雪計画路線の
選定を行い149路線， $2633 \mathrm{~km}$ を設定し，バス事業 者や市町村が機材や費用を分担して除雪が開始され た。これは，北海道における最初の総合的な除雪計 画と位置づけられる。このころ札幌市の清掃課長が 污物の搬送路を確保する目的での雪対策の見通しに ついて個人的な見解としながらも気象予測を行って いる ${ }^{\prime}$ 。各年の降雪及び気温の推移を図にし, 昭和 24年が昭和 20 年度に似た形となっていることを根抛 に，今年度の降雪のピークは過ぎ，1月中旬以降の 大雪はないことを考慮した冬期対策の実施計画を立 てることを進めている。個人的な見解としながらも 除雪計画に気象情報を利用することが自然発生的に 開始された（図 1)。

昭和31年には「積雪寒冷地域における冬期交通確 保等に関する特別措置法（雪寒法）」が制定され， 除雪延長が伸びるとともに，除雪作業の出動基準, 作業基準等が明確化され, 正確で, きめ細かな道路 周辺の気象情報が求められるようになる。

昭和42年には，豪雪と冬期オリンピックの札幌開 催決定をうけて「札幌市除雪対策専門委員会」が設 置されたが，まだ情報関連のテーマは見られない。

昭和50年代にはいり，モータリゼーションを背景 とした市民二ーズの高まりをうけて除雪のレベルアッ

* (狱)北海道開発技術センター理事 


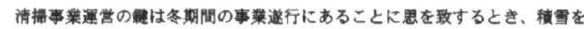
何如に克服するかが重大な点と思っている。最少の経費之経済的な労力の消费

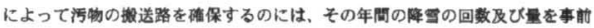

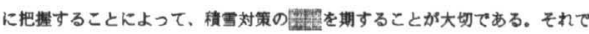
今回昭和二十年度本来の降鲁量と平均気温を中央気像台札媦支部の資料により 作製し、素人考えてはあるが、本年度の降管に対する想定を榭立して見た。勿

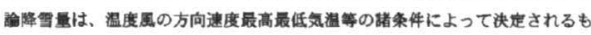
のて、単級に例年の降雪量と平均気温で見通しを付けることは、一面無視の感

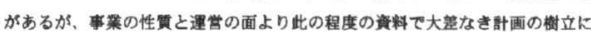
支颜なきものと责えた。

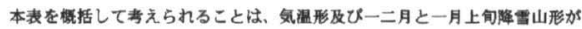
昭和三○年と同形の山形をなしていることより、本年度の降雪形態は、二十年 度梨と想定、糟雷量を $500 \mathrm{~cm}$ 程度と考える。降雪期は同年度に比し三日乃

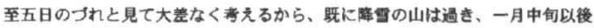
には、大降雪敏をものと思う。跣諭として本年度冬期対策の实施に籍手すべき

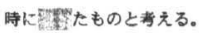

本表が闌保各方面の事厸に何等かの荠考にもなれば幸いと考え、ブリントと した。

昭和二五年一月一六日 清搰課長

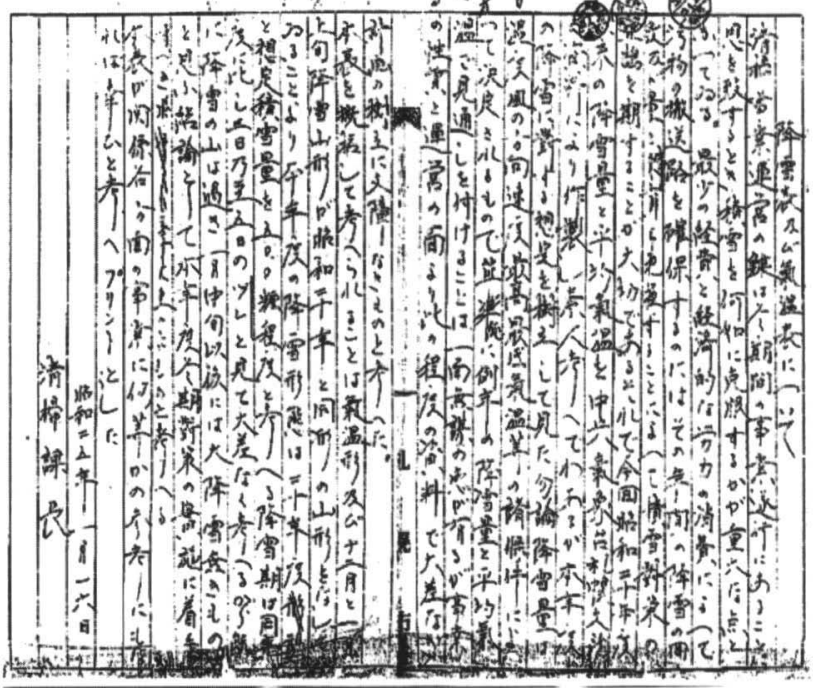

図 1 気象情報の雪対策利用のはじまり（札幌市）

プが急激に進み、雪による物理的な障害が少なくな る。しかも，企業や社会経済活動は，在庫を置かな い体制が一般化し，物流に対して高い，定常性，定 時性を求める社会へと変化しはじめ, 新たな雪対策 が模索される時期にきていた。この時期には, 道路 情報板や道路周辺の気象観測テレメータの配備など がはじまっていた ${ }^{11 。}$

昭和60年には，時代の変化をうけて北海道開発庁 (現国道交通省)によって「ふゆトピア」が提唱さ れ，ふゆトピア事業の中で，はじめて道路情報シス テムが施策の一つの柱となり，峠部を中心に総合的 な道路情報システムの整備が行われた ${ }^{3,4) 。 ま た, ~}$ ふゆトピアの一環として札幌市で策定された「雪さっ ぽろ21計画」5) の中には，降雪予測等を含む総合的 な冬期道路交通情報システムが構築された。

スパイクタイヤの使用規制が法制化され，平成 5 年には札幌市のスタッドレスタイヤ装着率がほぼ100 \%となった。しかし，スタッドレスタイヤも一因と 考えられるツルツル路面が頻発するようになる。凍 結防止剂散布を中心とした路面対策が実施されるが, 路面状態や散布時期によつて効果が異なるため, 路 面や気象情報の詳細な把握が行われた。

しかし、ツルッル路面問題は, 道路管理側だけの
対応では難しいのが現状である。そのため, 道路ユー ザーであるドライバーや歩行者に対しての情報提供 による危険回避を促す必要があり，インターネット や携帯電話により, 道路ユーザーに直接, 道路交通 情報を提供する試みがはじまっている。

気象情報を中心に除雪作業の効率化を目的にはじ まった北海道の冬期道路情報システムは, 情報通信 機器の技術革新と家庭への急速な普及によって, 道 路ユーザーへの危険回避行動を促す目的にまで使用 範囲が広がってきている。

\section{3. 冬期道路情報システムの現状}

北海道における冬期道路情報システムの現状につ いて，情報収集，情報提供，総合情報システムに分 類して紹介する。

\section{（1）情報収集}

北海道内で使用されている情報収集機器には, ITV カメラ, 車両感知器, 気象テレメータ, 視程 や路面凍結検知器等がある。

既に北海道内の国道周辺には200力所以上の道路 気象テレメータが設置されており, 風向, 風速, 気 温, 路面温度, 積雪深, 雨量などについて情報収集 を日夜行っている。これらのデー夕は, 無線や光ケー 


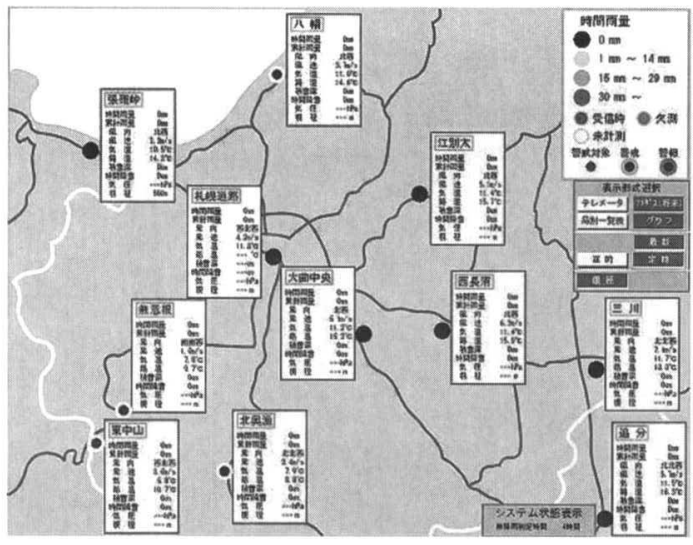

図 2 道路気象テレメータ ${ }^{6)}$

ブルを使って集められ，図 2 のように時間雨量を 4 段階の強さで表示される。端末は, 国道を管理する 北海道開発局, 各建設部, 道路事務所などに設置さ れ，24時間体制で監視している ${ }^{6)}$ 。

現状では国道管理者が, 道路通行止め等の意志決 定の支援や日常的な管理作業の中で使用されている。

特に吹雪や凍結路面が頻繁に発生する箇所には視 程計, 凍結路面計が設置されている。路面凍結計は, 変調光を道路面に投光し, その反射光を 2 個のフォ トダイオードで正反射, 乱反射として受光, それら の大小を比較することにより路面上の雪水の有無を 非接触で検出する。視程計は, 空気中に霧や雪があ ると透過率が減少することを利用して, 道路上 $30 \mathrm{~m} \sim 50 \mathrm{~m}$ の可視光, 透過率を測定する (図 3$)^{6)}$ 。

\section{（2）情報提供}

収集した道路情報は, 情報処理され加工されて, 道路ユーザーや道路管理に係わる人たちに提供され

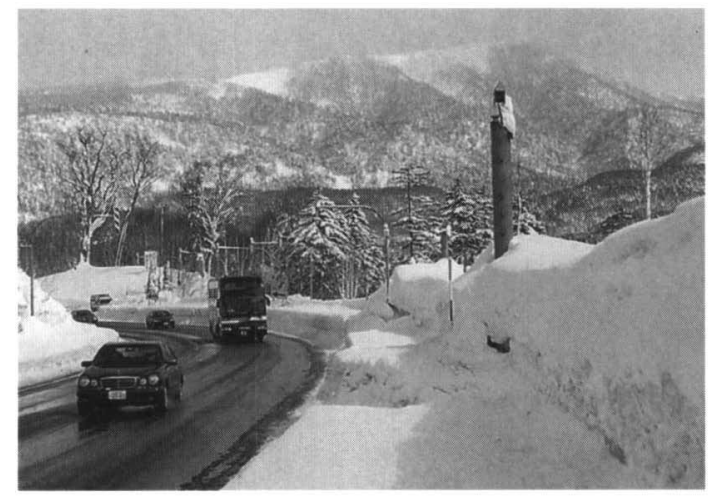

図 3 視程計（国道230号中山峠）
る。情報提供の基本ツールは道路情報板と路側通信 である。また, インターネットの発展を背景にホー ムページや携带電話による情報提供基盤も整備され, 年々，内容も充実してきている。

道路情報板は, 小さいものは道路標識から大型の 電光掲示式のものまで, 様々なものがある。最近, 温度センサーで観測した路面温度や気温をドライバー に提供する情報板の整備が進められている。気温が $0{ }^{\circ} \mathrm{C} \sim-5{ }^{\circ} \mathrm{C}$ 範囲で路面に雪水がある場合には, 滑りやすいことは，北国や雪国に住むドライバーに は周知のことであるが, 観光でドライブをする運転 者などへの啓蒙が課題である。

道路情報板は，おおむね $100 \mathrm{~m}$ 程度離れた所から 道路情報板が視認できることが基本要件となってい る。利用状況については，90\%近くが必ず見ており， 道路情報板の情報が役立つとする割合も $90 \%$ 程度と 高い。課題としては, 文字を大きく見やすくするこ とが上げられている ${ }^{3)}$

山川他”の実験によれば，昼間はマルチカラー LED, 夜間は電光式表示機と高解像 LED 式表示が 有効と報告している。色は，昼間は緑，夜間は赫が 最も良く，黄色は昼夜ともに比較的高い。青は，い ずれの場合も最も低いと報告している。

同時に分散設置による視認性確保についても実験 を行い, 情報文を分割・分散配置し, 車両の走行に よる連続提供という手法に一定の効果を見いだして いる。

路側通信は, 道路情報板や一般のラジオ放送など を補完する手段と位置づけられる。北海道土木技術

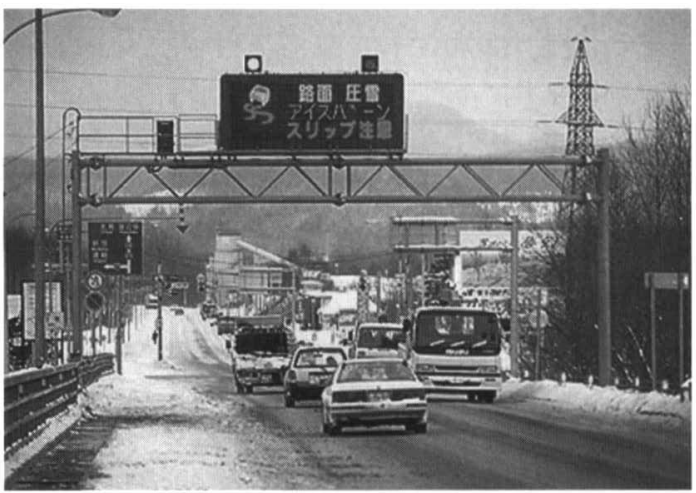

図 4 大型道路情報板 


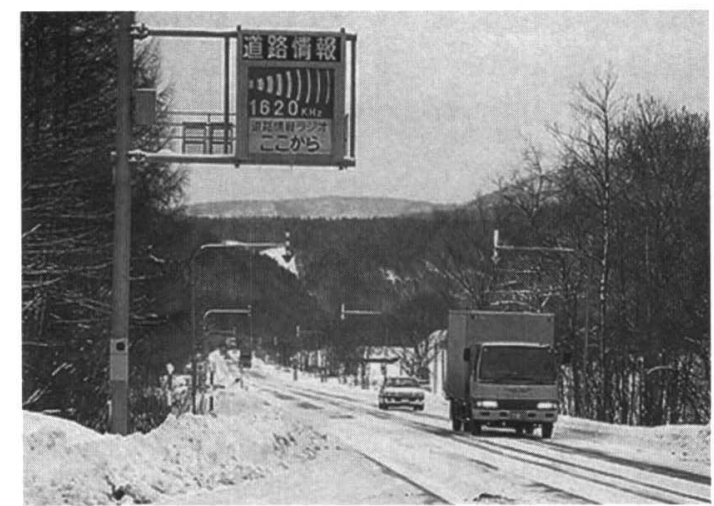

図 5 路側通信

会 ${ }^{7)}$ や札幌開発建設部 ${ }^{31}$ の調査によれば, ドライ バーの認知度は高く, 利用状況も増加傾向にある。

また，運転歴が長いプロのドライバーほど利用が多 い。彼らの関心は路面状況であり, 課題として, 提 供内容の充実が上げられている。

インターネットによる情報提供に「北の道ナビ」 (http://northern-road.jp/navi/) がある。北海道 道路情報化研究会 (北海道開発局, 北海道, 札幌市, 日本道路公団北海道支社）が中心となって, 北海道 内の道路関連情報を一元化して, 道路ユーザーのア クセスを容易にすることを目的として平成 11 年 7 月 に開設された。

「北の道ナビ」は北海道の道路に関連する情報を 体系的にまとめた総合案内サイトである。その内, 冬期道路に関しては, 道内 3 峠の道路画像へ, トッ プページから直接アクセスできるほか, 札幌総合情 報センターや(財)気象協会のホームページ等とリンク した気象サイトも搭載している。他に, 道内の道路 マップや冬期通行止め区間などの情報も盛り込まれ, インターネットユーザーから高い評価を受けている9!。

また, ある損害保険会社北海道本部では, 自社に 蓄積された自動車事故デー夕を基に積雪期の気象デー 夕と事故件数の関係を重回帰分析によって見いだし

\section{た「冬期自動車事故発生頻度警報システム（俗称：}

事故とっと減る) をホームページで公開している ${ }^{10}$ 。 道路管理者の情報提供サイトでは，管理瑕疪等の 問題もあり，警報を出すまでにはいたっていないこ とから，先導的な取り組みである。たとえ警報が外 れても, 注意喚起の意味は大きい。しかし, 的中精

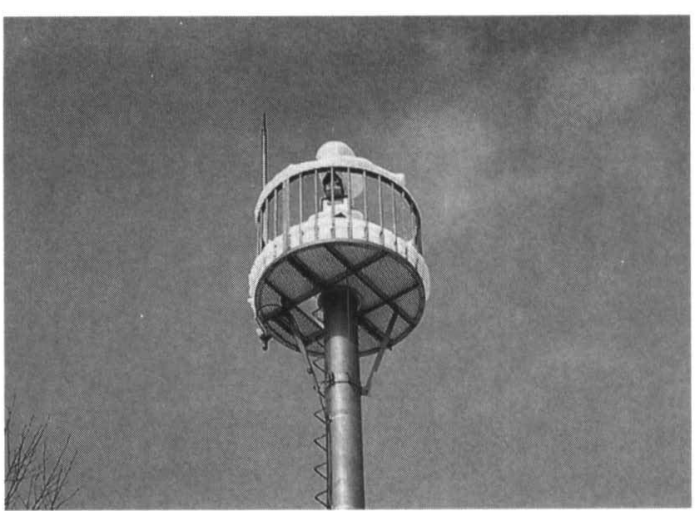

図 6 ITV カメラ（国道230号中山峠）

度があまりに悪いと信頼性が無くなり, 注意喚起の 効果も無くなることから，精度の向上がポイントと 考えられる。

\section{（3）総合情報システム}

このような情報機器を総合的に組み合わせたシス テムの事例として, 都市間における峠情報システム, 都市部における札幌総合情報センターがある。

\section{1) 峠情報システム ${ }^{11}$}

峠情報システムは, 石北峠（国道39号），日勝峠 (国道274号), 中山峠 (国道230号) の 3 力所に設置 されている。

情報収集用の ITV カメラ, 車両感知器, 気象テ レメータ, 視程計や路面凍結検知器等と情報提供の ための, 道路情報板, 路側通信, 道の駅, 道路情報 ターミナルが総合的に配備されている。

\section{2 ) 札幌総合情報センター（SNET）}

札幌総合情報センターは, 札幌市によって設置さ れた第 3 セクターである。SNET のシステムは, 降 雪予測, マルチセンサー, ロードヒーティング制御, 除雪運用支援の各サブシステムで構成されている ${ }^{13)}$ 。

降雪予測は, 長時間予測（24時間先まで気象）と 短時間予測がある。長時間予測は, 市内10区をそれ ぞれ 2 地域に分割して予測する。短時間予測は気象 レーダーのレーダーエコーを外挿する手法を基本に 3 時間先までの降雪量を $1 \mathrm{~km}$ メッシュで予測する。

マルチセンサーは, 各種気象センサーを一体化し た気象テレメーターであり，市内を中心に $4 \sim 5 \mathrm{~km}$ 間隔で52力所設置されている。観測データは，10分 ごとに専用電話回線で集積され，ほぼ同時に気象情 
報配信端末に送られる。この情報送信システムを 「そらみる (SORAMIL)」と呼んでいる ${ }^{12}$ 。

気象情報の配信端末は, ゾーンごとの除雪組織の 事務局となる除雪センターに配備され, 降雪予測や 現状の正確なデータに基づいて除雪や路面凍結の作 業計画が立案され，実施される。

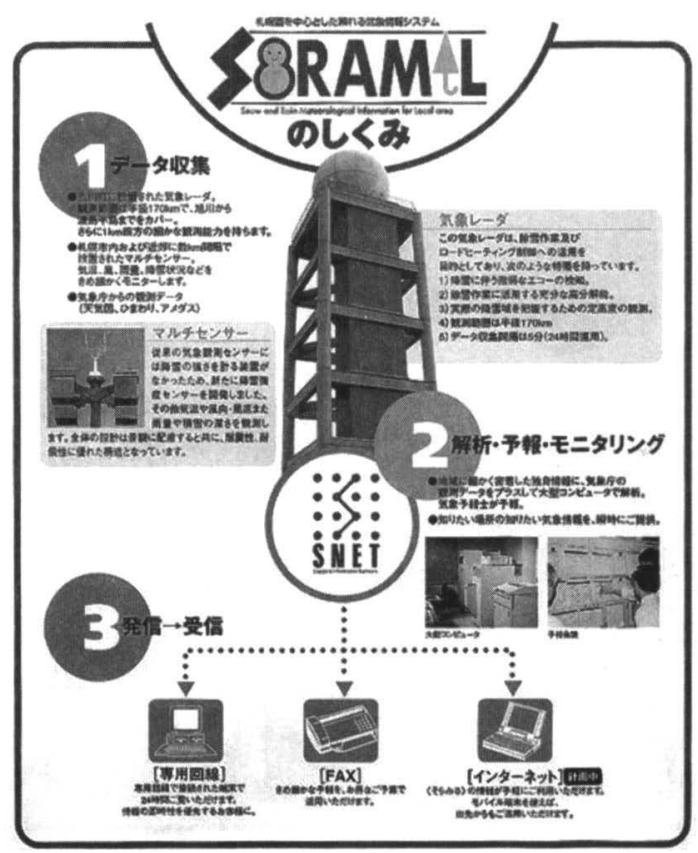

図 7 気象情報送信システム $(S N E T)^{12)}$

\section{4. 冬期道路情報システムの先導的実験}

インターネット, 携帯電話等の新しい通信技術が 普及し一般化する中で，このような通信技術を駆使 した新しい冬期道路情報システムの実験を紹介する。

\section{1 ）スマート札幌ゆき情報実験 ${ }^{14)}$}

北海道開発局開発土木研究所を中心にインターネッ 卜と携帯電話によって, 各種の雪情報を提供する実 験が行われている。

提供情報は 4 種類で, 通勤通学ゆき情報（希望す るエリアの降雪量, 気温, 路面状態などを朝夕 2 回 提供する。）, 札幌雪情報（交通ターミナルやスキー 場の気温, 降雪予測, 天気予測を Web で提供),

事業者向け情報（事業運転手に移動経路上の道路情 報, 気象情報を提供), ユキの窓 (通勤通学ゆき情 報の内容にモニター同士の伝言板を設置) である。

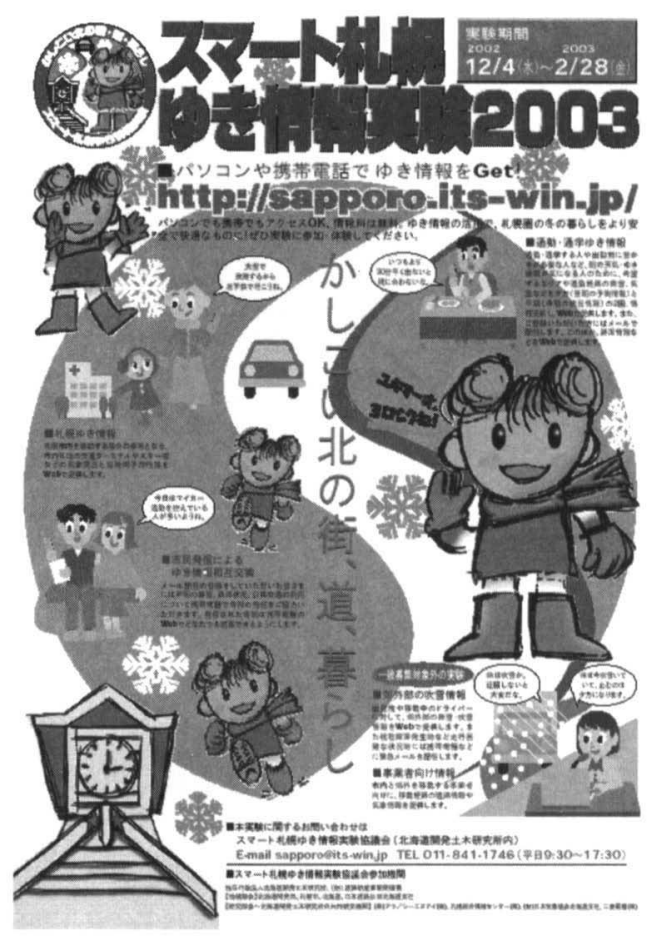

図８スマート札幌ゆき情報実験ポスター

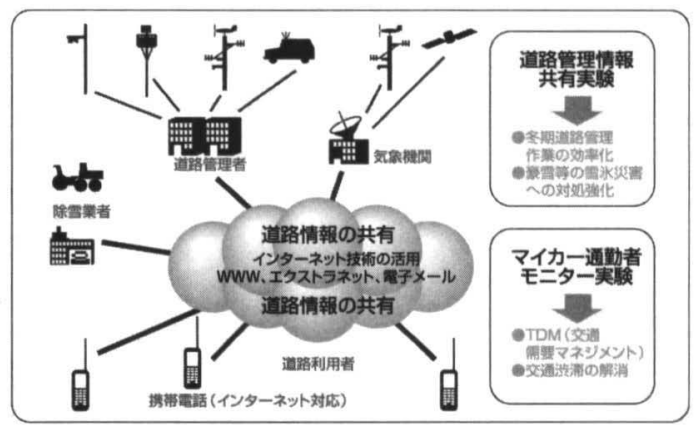

図 9 札幌圏ホワイトネット構想 ${ }^{6}$

実験は 3 年間継続中であり, 平成 14 年 1 月〜 2 月 の実験結果では，モニターの 8 割が通勤通学行動に 有効だったと回答し, マイカー利用者の 6 割は, 通 勤通学行動を変更している。具体的な行動変更は, ほとんどが出発時間の変更で, 気象条件が厳しい日 ほど, 行動が変更される割合が高いと報告している。 このような結果に基づいて冬期道路情報提供が TDM 施策として成立する可能性を示唆した。

\section{2 ）札幌圈ホワイトネット構想 ${ }^{15}$}

札幌開発建設部と北海道開発局開発土木研究所を 中心に, 札幌圏の道路管理者がそれぞれ保有する工 
事情報, 通行規制情報，除雪作業情報等の道路管理 情報と気象情報や画像情報を, インターネットやメー リングリストを利用して共有する実験が行われてい る。

目的は, 冬期道路管理作業の効率化, 豪雪時の雪 氷災害への対応である。組織間の障壁がある中で, それを乗り越えて，スムースな作業連携と面的に整 合のとれた冬期道路管理を目指している。また，将 来的には道路ユーザ一等の一般にまで, リアルタイ ムで道路情報を提供することを視野にいれている。

\section{3）寒冷地 AHS（走行支援システム）}

北海道開発局開発土木研究所では, 冬期道路にお けるドライバーの安全走行を支援するシステムの基 礎研究が行われている。具体的には, 前方の障害物 や広域の気像情報をドライバーに提供して注意喚起 を促す。情報提供には車載端末と自発光デリネータ を用いて危険警告を行うる。

\section{5. 今後の展望}

北海道の冬期道路情報システムの現状を紹介する とともに，既存研究報告のリビューを行った。その 結果, 今後の冬期道路情報システムの展望として, 情報の提供対象の個別化, 情報の共有化, 統合化の 推進, 双方向の情報交換の 3 つがポイントと考えら れる。

\section{1）情報の提供対象の個別化}

北海道における冬期道路情報システムの現状をみ ても，主に道路管理者，除雪等の作業を行う方を対 象としたものが多い。ラジオ, テレビ等のマスコミ が，気象情報や交通情報を放送しているが，内容的 に物足りないものであった。

しかし、インターネットや携帯電話の普及によつ て，個別に情報を提供する基盤ができあがり，冬期 道路情報システムも新たなステージに入った。その ため，情報はきめ紐かく，個別ニーズに対応するこ とが求められており，対応するソフトの量と質の充 実は緊急の課題となろう。

\section{2）情報の共有化, 統合化}

機関別や部署別に縦割りになっている冬期道路情 報を共有又は統合することによって，道路管理者間 の連携を容易にし，除雪レベルを面的に向上させる ことができる。特に，豪雪時には短時間に情報を共 有する必要性が高い。また，道路ユーザーや住民が 正確な情報がないことによるイライラなども減少す る。

課題としては，情報を共有することによるセキュ ウリテイの確保，インターネット上での情報交換を 容易にする技術，組織的な慣習や規則の变更などが ある。

加治屋等 ${ }^{163}$ が研究開発した道路用 Web 記述言語 RWMLは，XML 技術を抎張したもので，ホーム ページ上での情報のやりとりを極めて容易すること から，技術的な部分の解決はすすみつつあるが，組 織ごとの意識改革などには，もう少し時間がかかる であろう。

\section{3）双方向の情報交換}

一般的な冬期道路情報システムは，道路ユーザー や一般市民に対して一方的に情報を提供する形態で ある。しかし，札幌圈ホワイトネット構想のユキの 空に見られるように，モニターが自ら情報発信を行 い，情報が相互に行き来する形式が見られるように なってきた。

背景として携帯電話やインターネット等の普及に よる所は大きいが，個別ユーザーがシステムに参加 することによって，よりきめ紐かな情報をリアルタ イムで収集が可能となり，システム全体の信頼度も 向上する。

したがって，今後は道路ユーザ一や一般市民を道 路情報システムの中に，どのように組み込むかが， 課題である。

最後に, 冬期道路情報システムは, 冬の道路交通 の維持に有益な手法の一つではあるが，その効果を 定量的に把握した事例は，少なくとも北海道内には ない。田邊 ${ }^{17)}$, 加治屋 ${ }^{18)}$ などの研究はあるが, 基本 的な考え方の整理に留まっており, 定量的（貨幣ター ム）な把握手法の開発も重要な課題である。 


\section{参考文献}

1) 原 文宏, 新森紀子：除雪史に関する研究 (1), 寒地技術シンポジウム論文報告集，Vol.16， pp623-626, 2000

2 ）渡邊定雄：札幌市の除雪, 昭和58年

3) (社北海道開発技術センター: 平成 3 年度快適な 冬の生活環境づくり「ふゆトピア」事業推進調 查報告書, 平成 4 年

4) 北海道開発庁：快適な冬の生活環境づくり「ふ ゆトピア」(パンフレット)，㯦北海道開発協会 発行, 平成元年度

$5 ）$ 札幌市道路維持部：雪さっぽろ21計画, 平成 3 年度

6 ）2002PIARC 国際冬期道路会議札幌大会実行委 員会: Technical Visit Guide Book, 2002

7）北海道土木技術会：冬期の道路交通情報システ 厶に関する研究，平成 2 年度調查研究報告書, 平成 3 年

8）山川淳一, 山崎和夫, 石岡雅洋 : 冬期道路にお ける道路情報装置に関する研究報告（分散設置 型情報板について）寒地技術シンポジウム論文・ 報告集，Vol.15，pp663-670，1999

$9 ）$ 加治屋安彦、和田忠幸, 石塚健司：インターネッ 卜道路情報システム「北の道ナビ」と地域活性 化（北海道道路情報ポータルサイト開設と旅・ 風景@北の道再発見コンテスト等)，寒地技術シ ンポジウム論文・報告集, Vol.15, pp646-651， 1999

10) http://www.hokkiado.tokiomarine.co.jp/ jiko.heru/gaiyou.html

11）北海道開発局監修：北海道開発局の冬期道路管
理, 財北海道道路管理技術センター発行, 平成 6 年

12）札幌総合情報センター㑣：札幌圈を中心とした 頼れる気象情報システム「SORAMIL（そら みる)」(パンフレット)

13）青山 彰：冬期道路交通情報システム（札幌総 合情報センター）-SNETー, 北の交差点, Vol. 4, 財)北海道道路管理技術センター, pp12-17, 1998

14）加治屋安彦，山際祐司，三好達夫，加賀屋英和， 山口敏之：雪情報が市民の交通行動に与える影 響について（第 3 報）一スマート札幌ゆき情報 実験2002－，寒地技術シンポジウム論文報告集， Vol.18, pp21-28, 2002

15）金田安弘, 金子正夫, 加治屋安彦, 長利秀則, 上村啓二, 神谷誠司：道路管理者間の冬期道路 管理情報共有システム（ホワイトネット），寒地 技術シンポジウム論文・報告集、 Vol.17, pp183-190, 2001

16）加治屋安彦, 松沢 勝, 千葉隆広：インターネッ 卜技術の道路情報分野への活用一道路用 Web 記述言語 RWML 策定の提案一，寒地技術シン ポジウム論文・報告集, Vol.14, pp99-106, 1998

17）田邊慎太郎：道路情報の価値に関する一考察, 寒地技術シンポジウム論文・報告集，Vol.17， pp653-658, 1988

18）加治屋安彦，松沢 勝，金田安彦，今井正博： 寒地 ITS の評価方法について，寒地技術シン ポジウム論文・報告集, $\mathrm{V}$ ol.17, pp653-658, 1988 